\title{
Intubação Nasotraqueal Guiada por Rinoscópio em Criança de Um Ano de Idade Portadora de Osteogenesis Imperfecta. Relato de Caso *
}

\section{Rhinoscope-Guided Nasotracheal Intubation in a One-Year Old Child with Osteogenesis Imperfecta. Case Report*}

\author{
Eduardo Toshiyuki Moro, TSA ${ }^{1}$, Francisco Carlos de Andrade Júnior ${ }^{2}$, Renato Augusto Andrade ${ }^{2}$, \\ Sérgio Penteado de Camargo Oliveira Júnior ${ }^{3}$
}

\section{RESUMO}

Moro ET, Andrade Jr FC, Andrade RA, Oliveira Jr SPC - Intubação Nasotraqueal Guiada por Rinoscópio em Criança de Um Ano de Idade Portadora de Osteogenesis Imperfecta. Relato de Caso

JUSTIFICATIVA E OBJETIVOS: A Osteogênesis Imperfecta (OI) é uma rara doença genética de herança autossômica dominante. $A$ anestesia para o paciente portador da OI inclui diversos desafios, entre eles o manuseio da via aérea e a escolha da técnica anestésica. O objetivo do presente artigo foi descrever caso de criança portadora desta doença associada à hidrocefalia, submetida à anestesia venosa total e intubação nasotraqueal guiada por rinoscópio para realização de derivação ventrículo-peritoneal.

RELATO DO CASO: Paciente do sexo masculino, um ano e três meses de idade, com diagnósticos de OI (tipo III) e hidrocefalia submetido à derivação ventrículo-peritoneal. Após a administração de midazolam (1 mg. $\mathrm{kg}^{-1}$ ) por via oral 30 minutos antes do procedimento, a criança foi monitorizada, seguindo-se a venóclise com cateter 24G. Após oxigenação, procedeu-se à indução anestésica com remifentanil, propofol e cisatracúrio. A intubação nasotraqueal foi guiada por rinolaringoscópio (Olimpus ${ }^{\circledR}$ ENF P3) e cânula de 4,5 $\mathrm{mm}$ com balonete foi inserida sem intercorrências. A anestesia foi mantida com infusão de remifentanil e propofol. A operação teve duração de 120 minutos, sem intercorrências.

CONCLUSÕES: O presente relato descreveu alternativa de acesso à via aérea em crianças submetidas à anestesia geral e que por algum motivo não podem ser ventiladas através da máscara laríngea. O rinolaringoscópio, por apresentar diâmetro reduzido, permite a inserção de cânulas traqueais que não poderiam ser utilizadas com o emprego do fibroscópio convencional.

Unitermos: ANESTESIA, Geral: venosa; DOENÇAS, Genética: osteogênese imperfeita; INTUBAÇÃO, Traqueal: nasotraqueal.

\footnotetext{
${ }^{*}$ Recebido do Hospital UNIMED de Sorocaba, SP.

1. Anestesiologista; Corresponsável CET/SBP da Faculdade de Medicina da PUC/SP

2. Médico Neurocirurgião do Hospital UNIMED de Sorocaba

3. Cirurgião Torácico do Hospital UNIMED de Sorocaba
}

Apresentado (Submitted) em 10 de dezembro de 2008

Aceito (Accepted) para publicação em 20 de maio de 2009

Endereço para correspondência (Correspondence to):

Dr. Eduardo Toshiyuki Moro

Av. Araçoiaba, 85

Condomínio Lago Azul

18190-000 Araçoiaba da Serra, SP

E-mail: edumoro@terra.com.br

\section{SUMMARY}

Moro ET, Andrade Jr FC, Andrade RA, Oliveira Jr SPC - Rhinoscope-Guided Nasotracheal Intubation in a One-Year Old Child with Osteogenesis Imperfecta. Case Report.

BACKGROUND AND OBJECTIVES: Osteogenesis imperfecta (OI) is a rare, autosomal dominant disease. Anesthesia for patients with OI has several challenges; among them, management of the airways and the choice of anesthetic technique should be mentioned. The objective of this report was to describe the case of a child with this disorder associated with hydrocephalus who underwent total intravenous anesthesia and rhinoscope-guided nasotracheal intubation for a ventriculoperitoneal shunt.

CASE REPORT: This is a 15-month old male with OI (type III) and hydrocephalus who underwent placement of a ventriculoperitoneal shunt. After the oral administration of midazolam $\left(1 \mathrm{mg} \cdot \mathrm{kg}^{-1}\right) 30$ minutes before the procedure, the child was monitored and, afterwards, a 24G catheter was used for venipuncture. After oxygenation, anesthesia was induced with remifentanil, propofol, and cisatracurium. A 4.5- $\mathrm{mm}$ ETT with balloon was used for the rhinoscopeguided (Olimpus ${ }^{\circledR}$ ENF P3) nasotracheal intubation without intercurrences. Anesthesia was maintained with the infusion of remifentanil and propofol. The surgery lasted 120 minutes, without intercurrences.

CONCLUSIONS: The present report described an alternative for the access of the upper airways in children undergoing general anesthesia and who, for some reason, cannot be ventilated with a laryngeal mask. Since the rhinolaryngoscope has a reduced diameter, it allows the insertion of ETTs that could not be used with conventional fiberscopes.

Keywords: ANESTHESIA, General: intravenous; DISEASES, Genetic: Osteogenesis imperfecta; INTUBATION, Tracheal: nasotracheal.

\section{INTRODUÇÃO}

A Osteogênesis Imperfecta (OI) é uma rara doença genética de herança autossômica dominante, com incidência de aproximadamente um caso para cada 30.000 nascimentos ${ }^{1}$. A mutação de um ou dois genes, COL1A1 ou COL1A2, leva à síntese anormal do colágeno tipo 1, que é a proteína predominante na matriz óssea, resultando em fragilidade óssea, múltiplas fraturas e deformidades esqueléticas por deficiência na ossificação endocondral ${ }^{2}$. A anestesia para o paciente 


\section{Rhinoscope-Guided Nasotracheal Intubation in a One-Year Old Child with Osteogenesis Imperfecta. Case Report}

Eduardo Toshiyuki Moro, TSA, M.D. 1; Francisco Carlos de Andrade Júnior, M.D. 2; Renato Augusto Andrade, M.D. 2; Sérgio Penteado de Camargo Oliveira Júnior ${ }^{3}$

\section{INTRODUCTION}

Osteogenesis imperfecta (OI) is a rare, autosomal dominant disease, affecting approximately one in 30,000 live-born. Mutation of one or two genes, COL1A1 or COL1A2, leads to the abnormal synthesis of collagen type 1 , a predominant protein in the bone matrix, resulting in brittle bones, multiple fractures, and skeletal deformities due to a deficiency in endochondral ossification ${ }^{2}$. Anesthesia in patients with $\mathrm{Ol}$ involves challenges, such as the management of the airways and the risk to trigger malignant hyperthermia. This paper reports the case of a child with $\mathrm{OI}$ and hydrocephalus who underwent total intravenous anesthesia and rhinoscopeguided nasotracheal intubation for placement of a ventriculoperitoneal shunt.

\section{CASE REPORT}

A 15-month old male patient, weighing $6 \mathrm{~kg}$, with a diagnosis of Osteogenesis imperfecta (type III) and hydrocephalus, treated with vitamin $D$, calcium, and alendronate sodium was scheduled for elective placement of a ventriculoperitoneal shunt. In the pre-anesthetic evaluation, he had a history of fracture of the tibia during the heel stick test and of the femur. He had bone deformities in the lower limbs and rib cage and increased head diameter. Clinical and laboratorial exams did not show the presence of other congenital or systemic disorders. The child was active and showed normal neurological development. Oral midazolam (1 mg. $\left.\mathrm{kg}^{-1}\right)$ was administered 30 minutes before the procedure. In the operating room, he was placed over a warming blanket and monitored with electrocardiograph $\left(D_{\|}\right)$and pulse oximeter; a 24G catheter was used for venipuncture.

After oxygenation with $100 \% \mathrm{O}_{2}$ for three minutes, anesthesia was induced with a continuous infusion of remifentanil $(0.5$ $\mu \mathrm{g} \cdot \mathrm{kg}^{-1} \cdot \mathrm{min}^{-1}$ ) followed by the bolus administration of $3 \mathrm{mg} \cdot \mathrm{kg}^{-1}$ of propofol and $0.1 \mathrm{mg} \cdot \mathrm{kg}^{-1}$ of cisatracurium. Nasotracheal intubation was guided by a rhinolaryngoscope (Olimpus ${ }^{\circledR}$ ENF P3, with distal extremity of $3.4 \mathrm{~mm}$ and $530-\mathrm{mm}$ long), and a $4.5-\mathrm{mm}$ ETT with balloon was inserted without intercurrences. The radial artery was catheterized for continuous monitoring of the blood pressure. The patient was maintained with closed-system mechanical ventilation with reabsorption of $\mathrm{CO}_{2}$, and monitoring of expired carbon dioxide $\left(\mathrm{P}_{\mathrm{ET}} \mathrm{CO}_{2}\right)$ and esophageal temperature were added. Anesthesia was maintained with infusion of remifentanil $\left(0.3 \mu \mathrm{g} \cdot \mathrm{kg}^{-1} \cdot \mathrm{min}^{-1}\right)$ and propofol $\left(0.15 \mathrm{mg}^{\mathrm{kg}} \mathrm{kg}^{-1}\right.$. Two whole body X-rays were done immediately after anesthetic induction and after the surgery, which did not show any fractures during the procedure.

The surgery lasted 120 minutes, without intercurrences. The patient had a serene awakening, approximately 10 minutes after the discontinuation of the anesthetics. Morphine $(0.05$ $\mathrm{mg} \cdot \mathrm{kg}^{-1}$ ) and dypirone (30 $\mathrm{mg} \cdot \mathrm{kg}^{-1}$ ) were used for postoperative analgesia. The patient was transferred to the intensive care unit, where he remained until the next day, without intercurrences. He was discharged from the hospital on the third postoperative day.

\section{DISCUSSION}

Anesthesia for patients with $\mathrm{OI}$ has several challenges, including management of the airways and the choice of anesthetic technique. Although clinically $\mathrm{Ol}$ is characterized by the triad brittle bones, bluish sclera, and loss or decreased hearing, several complicating problems can be present, depending on the presence of associated diseases, such as congenital cardiopathies, neurological abnormalities, metabolic changes, and platelet dysfunction or cor pulmonale $^{3}$. The typical OI fascies with short neck, temporal and occipital projection, and prominent jaw can be associated with difficult airways. Besides, fractures of the cervical spine, jaw, and teeth, and mucosal contusions and hemorrhage should also be considered ${ }^{3,4}$.

In the present study, the child underwent total intravenous anesthesia with propofol and remifentanil, since the possibility of hyperthermia induced by inhalational anesthetics or the administration of succinylcholine was considered ${ }^{2}$. Children with OI seem to have characteristics compatible with hypermetabolic states and some characteristics similar to those of individuals susceptible to the development of malignant hyperthermia $(\mathrm{MH})$ : autosomal dominant or recessive inheritance, connective tissue abnormalities, and elevated serum levels of inorganic pyrophosphate ${ }^{5}$. Different authors have related $\mathrm{OI}$ with the development of $\mathrm{MH}^{6-8}$, although other mechanisms, still unknown, can be related with the development of perioperative hyperthermia ${ }^{5}$.

Regarding the airways, the use of the laryngeal mask has been suggested as an alternative for those cases, since it can be inserted with the patient in neutral cervical position, reducing the possibility of fractures of the cervical spine or jaw $^{4}$. However, ventilation of the child could be hindered by the position of the head during the surgery. Thus, rhinolaryngoscope-guided (Olympus ${ }^{\circledR}$ ENF-P3 with a distal diameter of $3.4 \mathrm{~mm}$ and $530 \mathrm{~mm}$ long) nasotracheal intubation was considered, since it was the flexible fiberscope with the smaller diameter available in the hospital,. Insertion of the ET tube did not cause significant mucosal bleeding.

One should also be careful during handling and monitoring. The patient should be carefully positioned in the operating table protecting areas subjected to compression. The use of 
the tourniquet or blood pressure cuff can cause fractures and/or vascular and tissue trauma and, for this reason, we chose catheterization of the radial artery to monitor the blood pressure.

The present report described an alternative to airways management in children undergoing general anesthesia who, for some reason, cannot be ventilated with the laryngeal mask. Since the rhinolaryngoscope has a small diameter, it allows the insertion of ET tubes that could not be used with conventional fiberscopes.

\section{REFERÊNCIAS - REFERENCES}

01. Karabiyik L, Çapan Z - Osteogenesis imperfecta: different anaesthetic approaches to two paediatric cases. Paediatr Anaesth, 2004; 14:524-525.

02. Porsborg P, Astrup G, Bendixen D et al. - Osteogenesis imperfecta and malignant hyperthermia. Is there a relationship? Anaesthesia, 1996;51:863-865.

03. Neves JFNP, Sant'Anna RS, Almeida JR et al. - Anestesia venosa total em paciente portador de osteogênesis imperfecta. Relato de caso. Rev Bras Anestesiol, 2004;54:668-671.

04. Karabiyik L, Parpucu M, Kurtipek O - Total intravenous anaesthesia and the use of an intubating laryngeal mask in a patient with osteogenesis imperfecta. Acta Anaesthesiol Scand, 2002;46:618-619.

05. Ryan CA, Al-Ghamdi AS, Gayle M et al. - Osteogenesis imperfecta and hyperthermia. Anesth Analg, 1989;68:811-814.

06. Rampton AJ, Kelly DA, Shanahan EC et al. - Occurrence of malignant hyperpyrexia in a patient with osteogenesis imperfecta. Br J Anaesth, 1984;56:1443-1446.

07. Masuda Y, Harada Y, Honma E et al. - Anesthetic management of a patient with osteogenesis imperfecta congentia. Masui, 1990;39:383-387.

08. Sadat-Ali M, Sankaran-Kutty M, Adu-Gyamfi Y - Metabolic acidosis in osteogenesis imperfecta. Eur J Pediatr, 1986;145:582583.
RESUMEN

Moro ET, Andrade Jr FC, Andrade RA, Oliveira Jr SPC - Intubación Nasotraqueal Guiada por Rinoscopio en Niño de un Año de Edad Portador de Osteogenesis Imperfecta. Relato de Caso.

JUSTIFICATIVA Y OBJETIVOS: La Osteogénesis Imperfecta (OI) es una rara enfermedad genética de herencia autosómica dominante. La anestesia para el paciente portador de la OI incluye diversos retos, entre ellos el manejo de la vía aérea y la elección de la técnica anestésica. El objetivo del presente artículo, fue describir el caso de un niño portador de esa enfermedad asociada a la hidrocefalia, y sometido a la anestesia venosa total e intubación nasotraqueal, guiada por rinoscopio para la realización de la derivación ventrículo-peritoneal.

RELATO DEL CASO: Paciente del sexo masculino, un año y tres meses de edad, con diagnósticos de OI (tipo III) e hidrocefalia sometido a la derivación ventrículo-peritoneal. Después de la administración de midazolam (1 $\mathrm{mg}^{\mathrm{kg}} \mathrm{f}^{-1}$ ) por vía oral, 30 minutos antes del procedimiento, el niño fue monitorizado, con posterior venoclisis con catéter 24G. Después de la oxigenación, se procedió a la inducción anestésica con remifentanil, propofol y cisatracurio. La intubación nasotraqueal fue guiada por rinolaringoscopio (Olimpus ${ }^{\circledR}$ ENF P3) y cánula de 4,5 mm con balón e insertada sin intercurrencias. La anestesia se mantuvo con infusión de remifentanil y propofol. La operación duró 120 minutos sin intercurrencias.

CONCLUSIONES: El presente relato describió una alternativa de acceso a la vía aérea en niños sometidos a la anestesia general y que por algún motivo no pueden ser ventilados a través de la máscara laríngea. El rinolaringoscopio, por presentar un diámetro reducido, permite la inserción de cánulas traqueales que no podrían ser utilizadas con el uso del fibroscopio convencional. 